\title{
Izin Dewan Pengawas dalam Kewenangan Penyadapan Komisi Pemberantasan Tindak Pidana Korupsi
}

\section{Permit from the Supervisory Board in the Authority of Tapping the Corruption Eradication Commission}

\author{
Oktavia Wulandari \\ Universitas Halu Oleo \\ E-mail: wulandarioktavia556@gmail.com \\ Muhammad Sabaruddin Sinapoy \\ Pascasarjana Universitas Halu Oleo \\ E-mail: sabaruddinsinapoy@yahoo.com \\ Kamaruddin Jafar \\ Pascasarjana Universitas Halu Oleo \\ E-mail: kamaruddinjafar88@gmail.com
}

\begin{abstract}
The position of the Supervisory Board within the KPK institution is as a Supervisory Agency. Placing the Supervisory Board as the issuer of the wiretapping permit is of course contrary to laws and regulations and legal theories/concepts. The Supervisory Board's permission regarding wiretapping is also against the confidentiality of wiretapping. Because it is very risky for leakage to occur because the Supervisory Board is formed and its membership is directly elected by the President of the Republic of Indonesia and of course in the implementation of its main duties and functions it will be very influential with the face of power that shapes it, especially when the case involves the ruler of the power organization of the Republic of Indonesia.
\end{abstract}

Keywords: Supervisory Board; Tapping Permit; KPK

\begin{abstract}
Abstrak: Kedudukan Dewan Pengawas di dalam kelembagaan KPK adalah sebagai Lembaga Pengawas. Menempatkan dewan Pengawas sebagai pemberi izin penyadapan tentu saja bertentangan dengan peraturan perundang-undangan dan teori/konsep hukum. Izin Dewan Pengawas terkait tindakan penyadapan juga bertentangan dengan kerahasiaan penyadapan. Sebab sangat riskan terjadinya kebocoran karena Dewan Pengawas dibentuk dan keanggotaannya dipilih langsung oleh Presiden RI dan tentu saja dalam pelaksanaan tupoksinya akan sangat berpengaruh dengan wajah kekuasaan yang membentuknya terlebih ketika
\end{abstract}


perkaranya menyangkut dengan penguasa organisasi kekuasaan Republik Indonesia tersebut.

Kata kunci: Dewan Pengawas; Izin Penyadapan; KPK

\section{PENDAHULUAN}

Lembaga KPK masih menempati peringkat tertinggi kepercayaan publik dalam hal penegakan hukum terutama kasus korupsi. Hal ini memang dipahami dari kenyataan bahwa banyak pencapaian positif yang dilakukan KPK. Perjalanan KPK sudah terbilang sangat bagus meskipun belum sangat maksimal, seperti berita mengenai operasi tangkap tangan (OTT) terhadap pelaku korupsi masih sering terjadi. Yang cukup menggemparkan adalah tertangkap tangannya 41 dari 45 anggota DPRD Kota Malang oleh KPK. Kemudian, tidak kalah menggemparkannya adalah berita mengenai tertangkap tangannya anggota DPRD Kota Mataram yang melakukan pemerasan terkait dengan dana bantuan rehabilitasi fasilitas pendidikan yang terdampak bencana gempa bumi Lombok, NTB. ${ }^{1}$

Pemerintah terus melakukan evaluasi terhadap kinerja KPK, karena meskipun beberapa kasus telah diungkap KPK, tetapi kinerjanya belum optimal, antara lain: (a) akibat belum diimbangi kinerja aparat penegak hukum yang maksimal; (b) Masih banyak peraturan perundang-undangan yang multitafsir, sehingga terkadang mempengaruhi kepastian dalam pengambilan kebijakan dalam penanganan korupsi; (c) sanksi hukum untuk pelaku tindak pidana korupsi masih dikatakan lemah sehingga dapat menurunkan kepercayaan masyarakat; (d) masih tebang pilih dalam pemberantasan korupsi; (e) Pengungkapan korupsi banyak pada tataran eksekutif menunjukkan bahwa selama ini KPK lebih banyak bekerja pada korupsi birokrasi, sedangkan wilayah korupsi politik dan yudisial masih dianggap kurang; (f) keterbatasan sumber daya manusia KPK sangat terbatas; (g) KPK tidak didesain untuk menegakkan hukum korupsi di semua lini. Selanjutnya banyak kasus korupsi birokratis yang ditangani kejaksaan dan kepolisian mengalami kemacetan, KPK harus mengawasi secara serius setiap proses penegakan hukumnya. Karena dengan kewenangan itu, diharapkan penanganan kasus-kasus korupsi birokrasi yang ada di Indonesia akan lebih efisien dan tidak koruptif. ${ }^{2}$

1 Wicipto Setiadi, "Korupsi di Indonesia (Penyebab, Bahaya, Hambatan dan Upaya Pemberantasan, Serta Regulasi)", Jurnal Legislasi Indonesia, Vol 15, No. 3, November 2018, hlm. 250.

2 Adnan Sutopo, "Peran Strategis Komisi Pemeberantasan Korupsi", Antikorupsi.org, https://antikorupsi.org/id/news/peran-strategis-komisi-pemberantasan-korupsi, diakses pada tanggal 27 Januari 2020. 
Berdasarkan beberapa faktor tersebut di atas, sehingga pemerintah menganggap perlunya melakukan revisi terhadap Undang-Undang KPK (UU KPK), dengan tujuan untuk dapat memperkuat kinerja KPK. Tetapi justru Perdebatan mengenai revisi UndangUndang Komisi Pemberantasan Korupsi ini malah menimbulkan banyak perdebatan baru, terdapat banyak penolakan dari masyarakat, tak terkecuali akademisi yang berasal dari berbagai universitas (seperti Universitas Indonesia) yang telah melakukan tekanan publik. ${ }^{3}$ Tetapi, setelah melalui proses dan drama panjang mengenai revisi UU KPK ini pada akhirnya di sahkan pada tanggal 24 September 2019 menjadi Undang-Undang Nomor 19 tahun 2019 tentang Perubahan Kedua atas Undang-Undang Nomor 30 tahun 2002 tentang Komisi Pemberantasan Tindak Pidana Korupsi dengan beberapa penghapusan terhadap pasal di dalam undang-undang lama dan beberapa penambahan pasal baru. Sejak itu mulailah bermunculan pro dan kontra mengenai penambahan pasal yang ada di dalam UU KPK terbaru ini. Beberapa poin di dalam pasal UU KPK terbaru ini di anggap berpotensi melemahkan atau bahkan riskan bisa melumpuhkan kerja KPK. Salah satunya dengan ditambahkannya Pasal 37A ayat (1) yang menyatakan "Dalam rangka mengawasi pelaksanaan tugas dan wewenang Komisi Pemberantasan Korupsi dibentuk Dewan Pengawas sebagaimana dimaksud dalam Pasal 21 ayat (1)". Pasal tersebut menggambarkan tujuan dari dibentuknya dewan pengawas. Namun Keberadaan Dewan Pengawas dianggap akan melemahkan independensi KPK dan riskan akan terjadinya perluasan wewenang oleh dewan pengawas. Terlebih terhadap penambahan Pasal 12 B ayat (1) yang menyatakan "Penyadapan sebagaimana dimaksud dalam Pasal 12 ayat (1), dilaksanakan setelah mendapatkan izin tertulis dari dewan pengawas". Pasal ini dapat berpotensi mempengaruhi di dalam prosedural penanganan serta akan dianggap menghambat dan atau melampaui kewenangan KPK dalam penyadapan sebagai bentuk proses hukum untuk pengungkapan sebuah fakta atau peristiwa hukum, dimana kewenangan tersebut di atur di dalam Pasal 12 ayat (1) yang menyatakan "Dalam melaksanakan tugas penyelidikan dan penyidikan sebagaimana dimaksud dalam Pasal 6 huruf e, Komisi Pemberantasan Korupsi berwenang melakukan penyadapan”. Oleh sebab itu banyak terjadi pro dan kontra terhadap penambahan beberapa pasal tersebut di atas. Refly Harun menilai undang-undang KPK yang di dalamnya mengatur segala tugas dan

3 Klareza Putri, "Masa Depan Pemberantasan Korupsi Pasca Revisi UU KPK”, Economica.id, https://www.economica.id/2019/09/20/masa-depan-pemberantasan-korupsi-pasca-revisi-uu-kpk/, diakses pada tanggal 02 Maret 2020. 
wewenang Dewan Pengawas sebetulnya memiliki niat dengan tujuan untuk mengontrol KPK.

Dalam tatanan tata Negara, sebagai lembaga independen maka KPK sebetulnya sudah memiliki pengawasnya sendiri yakni rakyat dan perwakilannya yang berada di DPR. Karena itu ciri dari lembaga independen seperti KPK itu pengawasannya langsung dari rakyat, secara sosial-politik. DPR juga masih bisa mengawasi tetapi tidak bisa intervensi kasus. Karena akan dimungkinkan adanya kontrol administratif, anggaran, dan sebagainya. Dan menurut dia, tidak sepatutnya dibentuk pengawas untuk KPK. Sebab, KPK juga sudah dikontrol dengan mekanisme pengadilan, sebab sekarang ini menurut saya KPK sudah sibuk sekali ketika praperadilan diperbolehkan, karena hampir semua penetapan tersangka dipraperadilankan, Dan bisa saja orang-orang tertentu; orang-orang kuat memenangkan itu. ${ }^{4}$ Dewan Pengawas seharusnya dibutuhkan dengan fungsi untuk mempercepat laju pemberantasan tipikor. Bukan menjadi penghambat pelaksanaan tugas dan kewenangan KPK, dan tentu saja mengawasi hal-hal yang bersifat etik moral. Penyadapan, penggeledahan, dan penyitaan merupakan bagian dari proses hukum dimana hal itu berada di dalam kewenangan dan ranah penyidik lembaga KPK atas persetujuan pimpinan KPK.

Tulisan ini bertujuan untuk menjawab apakah kedudukan dewan pengawas sebagai pemberi izin dari penyadapan tidak bertentangan dengan peraturan PerundangUndangan dan Teori/Konsep. Dan apakah izin dewan pengawas tidak bertentangan dengan kerahasiaan Penyadapan.

\section{METODE PENELITIAN}

Jenis penelitian yang gunakan dalam penelitian ini adalah penelitian hukum normatif. Penelitian hukum normatif merupakan suatu proses untuk menemukan aturan hukum, prinsip-prinsip hukum, maupun doktrin-doktrin hukum guna menjawab isu hukum yang dihadapi yang menghasilkan argumentasi, teori dan konsep baru sebagai preskripsi dalam menyelesaikan masalah. ${ }^{5}$ Tentunya yang berhubungan dengan permasalahan yang akan dibahas oleh penulis yaitu tentang Izin Dewan Pengawas dalam kewenangan Penyadapan Komisi Pemberantasan Tindak Pidana Korupsi. Dan juga dengan Penelitian kepustakaan

\footnotetext{
4 CNN Indonesia, "KPK Tak Butuh Dewan Pengawas", CNN Indonesia, https://www.cnnindonesia.com/nasional/20190910082044-20-428971/kpk-tak-butuh-dewanpengawas, diakses pada tanggal 02 Maret 2020.

5 Peter Mahmud Marzuki, Penelitian Hukum, Jakarta: Prenada Media Group, 2011, hlm. 35.
} 
(library research), yaitu penelitian yang dilakukan dengan mengumpulkan data dari bahan kepustakaan yang berhubungan dengan permasalahan yang diteliti. Pendekatan yang digunakan dalam penelitian ini adalah pendekatan (approach) yang digunakan dalam suatu penelitian normatif memungkinkan semua peneliti untuk memanfaatkan hasil-hasil temuan ilmu hukum empiris dan ilmu lain untuk kepentingan analisis serta ekspalanasi hukum tanpa mengubah karakter ilmu hukum sebagai ilmu normatif. ${ }^{6}$ Dan pendekatan Teori dan konsep hukum yang berkaitan dengan judul penelitian ini.

\section{ANALISIS DAN PEMBAHASAN}

\section{Dewan Pengawas Dalam Kelembagaan Komisi Pemberantasan Tindak Pidana Korupsi}

Komisi Pemberantasan Korupsi telah mencatatkan tinta emasnya dalam hal menyelamatkan keuangan Negara baik secara Preventif maupun Represif. Paling tidak tingkat kepuasan masyarakat terhadap Komisi Pemberantasan Tindak Pidana Korupsi cukup memuaskan, dan telah banyak pelaku tindak pidana korupsi yang telah diadili dan dipidanakan dan menyelamatkan miliaran rupiah aset Negara. ${ }^{7}$ Namun tidak dapat dipungkiri juga bahwa setelah lebih dari satu dasawarsa, Komisi Pemberantasan Tindak Pidana Korupsi ternyata tidak luput dari berbagai hal yang menyebabkan hilangnya proporsionalitas dan kredibilitas dalam mengawal pemberantasan korupsi. Terdapat beberapa faktor yang melatarbelakangi penilaian ketidak proposionalitas dan lemahnya kinerja KPK, salah satunya adalah lemahnya supervisi dan koordinasi komisi pemberantasan korupsi yang dinilai menyebabkan ketimpangan antar lembaga penegak hukum terkait luasnya kewenangan yang dimilik oleh komisi pemberantasan korupsi.

Dewan Perwakilan Rakyat periode 2014-2019, di akhir masa jabatannya mewacanakan untuk merevisi UU KPK, sebagai salah satu bentuk usaha meminimalisasi potensi penyalahgunaan wewenang KPK dengan instrument check and belances. Salah satu yang dibahas adalah tentang akan dibentuknya Dewan Pengawas Komisi Pemberantasan Korupsi. Presiden Jokowi sepakat dengan adanya Dewan Pengawas ini sehingga wewenang Komisi Pemberantasan Korupsi yang begitu luas dapat diawasi dan tidak

6 Johni Ibrahim, Teori dan Metodologi Penelitian Hukum Normatif, cetakan III, Malang: Bayumedia Publishing, 2007, hlm. 300.

7 Ermasjah Djaja, Memberantas Korupsi Bersama Komisi Pemberantasan Korupsi, Edisi Kedua, Jakarta: Sinar Grafika, 2010, hlm. 19. 
terjadi penyalahgunaan wewenang. ${ }^{8}$

Mahfud M.D. menilai bahwa KPK memang harus diawasi karena terkadang komisioner KPK sendiri tidak tahu bahwa ada operasi tangkap tangan. ${ }^{9}$ Hingga pada akhirnya rencana revisi Undang-Undang KPK tersebut disahkan dan Dewan Pengawas pun lahir dan terbentuk berdasarkan Undang-Undang Nomor 19 Tahun 2019 tentang Perubahan Kedua Atas Undang-Undang Nomor 30 Tahun 2002 Tentang Komisi Pemberantasan Tindak Pidana Korupsi. Dewan Pengawas dipilih oleh Presiden sehingga Presiden memiliki hak prerogatif di dalam memilih anggota-anggota dari Dewan Pengawas itu sendiri.

\section{Tarik Ulur Eksistensi Keberadaan Dewan Pengawas}

Pembentukan Dewan Pengawas KPK dengan lima anggota yang memiliki reputasi dalam bidang penegakan hukum dan pemberantasan tindak pidana korupsi terindikasi sebagai bagian dari kompromi politik oleh DPR dan Pemerintah untuk menghindari mekanisme perizinan penyadapan melalui pengadilan. Indikasi tersebut tercermin sebab berdasarkan Naskah Akademis Rancangan Undang-Undang tentang Perubahan Kedua Atas UU Nomor 30 Tahun 2002 tentang KPK yang berdasarkan hasil pengumpulan masukan dari pengadilan terutama di Samarinda dan akademisi Universitas Mulawarman, ke semuanya mendukung agar kewenangan penyadapan dibarengi dengan proses perizinan pengadilan sebagai kontrol agar tidak terjadi penyadapan yang melanggar hak asasi manusia, mengingat sifatnya dan tujuannya adalah pro-justicia untuk tujuan mencari alat bukti untuk keperluan persidangan. Memahami sifat kekhususan KPK dalam penyadapan sehingga untuk menjamin akuntabilitas dapat dibentuk Dewan Pengawas yang bertanggungjawab kepada DPR yang diatur secara khusus dalam undang-undang. ${ }^{10}$ Dari kriteria tersebut setidak-tidaknya mensyaratkan bagi lembaga-lembaga negara yang dalam pelaksanaan fungsi dan tugasnya melakukan pembatasan hak asasi manusia termasuk dalam penyadapan oleh KPK, maka harus mendapatkan pengawasan yang dapat dilakukan oleh 3 (tiga) elemen yakni (a) parlemen; (b) badan peradilan; atau (c) badan

8 Haris Prabowo, "Jokowi Setujui SP3 Kasus Korupsi dan Dewan Pengawas di Revisi UU KPK", Tirto.id, https://tirto.id/jokowi-setujui-sp3-kasus-korupsi-dewan-pengawas-di-revisi-uu-kpk-eh1X, diakses pada tanggal 11 Agustus 2020.

9 Hanz Jimenez Salim, "Mahfud MD Dukung Pembentukan Dewan Pengawas KPK", Liputan6, https://www.liputan6.com/news/read/4063398/mahfud-md-dukung-pembentukan-dewanpengawas-kpk, diakses pada tanggal 11 Agustus 2020.

10 Agus Suntoro, "Penyadapan dan Eksistensi Dewan Pengawas Komisi Pemberantasan Tindak Pidana Korupsi”, Jurnal Legislasi Indonesia, Vol. 17 No. 1, 2020, hlm. 33. 
independen. Meskipun secara konseptual dan ideal mengenai rezim pengawasan dan perizinan penyadapan melalui Hakim/Ketua Pengadilan, memiliki legitimasi hukum dan hak asasi manusia, akan tetapi di Indonesia pemikiran tersebut tidak sepenuhnya linear dengan persepsi publik terhadap lembaga peradilan. ${ }^{11}$

Beberapa alasan kurang tepatnya Dewan Pengawas KPK tercermin dari beberapa aspek dalam UU Nomor 19 Tahun 2019, yakni, pertama, Dewan Pengawas KPK menjadi satu kesatuan organisasi dengan KPK melekat bersama dengan Pimpinan KPK dan Pegawai KPK (Pasal 21 ayat 1) sehingga kelembagaannya tidak bersifat independen karena masih satu lembaga sehingga fungsi check and balance sangat diragukan; kedua, keanggotaan Dewan Pengawas KPK diangkat dan ditetapkan oleh Presiden Republik Indonesia, termasuk pemilihan Ketua Dewan Pengawas sehingga secara konseptual dan implementasi sangat tergantung pada wajah kekuasaan Presiden pada periode pengangkatan (Pasal 37E ayat 1 dan ayat 10); ketiga, dalam pelaksanaan tugas Dewan Pengawas KPK menggantikan peran dan fungsi peradilan terutama berkaitan dengan keseluruhan proses penegakan hukum di antaranya meliputi penyadapan, penggeledahan dan penyitaan padahal fungsinya bukan sebagai bagian dari penegakan hukum dalam criminal justice system. Oleh karena itu, untuk memastikan bahwa proses penyadapan dapat berlangsung dengan baik untuk kepentingan pembuktian dalam penegakan hukum (lawful interception) dan tetap menghormati hak asasi manusia sesuai dengan perintah konstitusi dan pengaturan internasional dalam pembatasan HAM, termasuk membuka ruang bagi komplain dan keberatan terhadap penyalahgunaan tindakan, maka secara ideal perlu meletakan rezim perizinan dan pengawasan di bawah pengadilan. Akan tetapi sebagai alternatif atas kebuntuan dan kekhawatiran publik terkait dengan persepsi integritas pengadilan ataupun persoalan birokrasi dan rawan kebocoran dengan sifat limitatif, rahasia dan kecepatan penyadapan, maka perlukah dibentuk independent body yang benar-benar mencerminkan kriteria dalam Siracusa Principles, bukan konsep Dewan Pengawas KPK dalam ranah UU Nomor 19 Tahun 2019. ${ }^{12}$

1 Ibid, hlm. 34.

12 Ibid, hlm. 35. 


\section{Kedudukan Dewan Pengawas dalam Kelembagaan KPK sebagai pemberi Izin terkait}

Penyadapan, Penggeledahan, dan/atau Penyitaan (P3)

Aspek check and balances sering kali dijadikan kata-kata yang menghiasi jalannya doktrin negara hukum, dimana dalam aspek ini setiap cabang saling mengimbangi kekuatan cabang-cabang yang lain. Dengan adanya perimbangan kekuasaan tersebut, diharapkan tidak terjadi penyalahgunaan kekuasaan di masing-masing organ kekuasaan itu. ${ }^{13}$ Secara asas, bahwa anggapan untuk mengimbangi semua kekuatan lembaga negara dengan melakukan pengawasan wajar dilakukan. Berdasarkan kajian yang dikeluarkan Indonesia Corruption Watch menyatakan ada tiga jenis model lembaga pengawas, yaitu model pengawasan internal, model pengawasan semi internal, dan model pengawasan eksternal. ${ }^{14}$

Berdasarkan Pasal 37B ayat (1) UU No. 19 Tahun 20019 tentang Perubahan Kedua atas Undang-Undang Nomor 30 Tahun 2002 tentang Komisi Pemberantasan Tindak Pidana Korupsi, dapat diketahui bahwa tugas Dewan pengawas adalah:

1. Mengawasi pelaksanaan tugas dan wewenang Komisi Pemberantasan Korupsi;

2. Memberikan izin atau tidak memberikan izin penyadapan, penggeledahan, dan/atau penyitaan;

3. Menyusun dan menetapkan kode etik pimpinan dan pegawai KPK;

4. Menerima dan menindaklanjuti laporan dari masyarakat mengenai adanya dugaan pelanggaran kode etik oleh pimpinan dan pegawai KPK atau pelanggaran ketentuan dalam UU;

5. Menyelenggarakan sidang untuk memeriksa adanya dugaan kode etik oleh pimpinan dan pegawai KPK; dan

6. Melakukan evaluasi kinerja pimpinan dan pegawai KPK.

Sebagai bagian dari struktural KPK, maka Dewan Pengawas dapat dikategorikan sebagai model pengawasan internal. Model ini dilakukan dengan membentuk sebuah unit pengawasan sebagai salah satu divisi kerja dalam sebuah lembaga yang akan diawasi. kewenangan untuk memberikan izin atau tidak memberikan izin penyadapan, penggeledahan, dan/atau penyitaan dikhawatirkan akan menghambat kinerja KPK dalam

13 Ni'matul Huda dan Imam Nasef, Penataan Demokrasi dan Pemilu di Indonesia Pasca Reformasi, Jakarta: Kencana, 2017, hlm. 27

14 Hario Dhanang Pambudhi, "Tinjauan Ketatanegaraan Dewan Pengawas KPK", Fakultas Hukum Universitas Padjadjaran, http://fh.unpad.ac.id/tinjauan-ketatanegaraan-dewan-pengawas-kpk/, diakses pada tanggal 12 Agustus 2020. 
memberantas korupsi. Dalam putusan nomor 36/PUU-XV/2017 tentang hak angket DPR terhadap KPK, Mahkamah Konstitusi berpendapat bahwa penggunaan hak angket tidak dapa dilakukan ketika KPK menjalankan tugas penyelidikan, penyidikan, dan penuntutan sebab independensi dan bebasnya KPK dari pengaruh kekuasaan mana pun adalah dalam melaksanakan tugas dan wewenangnya. Dalam putusan Mahkamah Konstitusi nomor 012016-019/PUU-IV/2006, Mahkamah Konstitusi berpendapat bahwa rumusan pasal independensi KPK berarti bebas dari pengaruh mana pun dalam melaksanakan tugas dan wewenangnya sehingga tidak terdapat persoalan konstitusionalitas dalam pasal tersebut. Karenanya, secara tidak langsung Mahkamah Konstitusi menyatakan status KPK sebagai lembaga independen. bahkan dalam putusan Mahkamah Konstitusi nomor 5/PUUIX/2011, Mahkamah menyatakan bahwa "KPK adalah lembaga negara independen yang diberi tugas dan wewenang khusus antara lain melaksanakan sebagian fungsi terkait kekuasaan kehakiman untuk melakukan penyelidikan, penyidikan dan penuntutan serta melakukan supervisi atas penanganan perkara korupsi yang dilakukan oleh institusi negara lain. Cara berpikir ini dapat diletakan dalam kemungkinan menolak pemberian izin oleh Dewan Pengawas kepada KPK saat melakukan penyadapan, penggeledahan, dan penyitaan sebagai bagian dari penyelidikan dan penyidikan. Walaupun Dewan Pengawas adalah mekanisme pengawasan internal, namun hakikat pengawasan dalam memberikan izin akan menghambat kinerja KPK dalam memberantas kasus korupsi. Sehingga independensi KPK dalam melaksanakan tugasnya sulit dipertahankan karena mendapat intervensi dari dalam tubuhnya sendiri. ${ }^{15} \mathrm{Hal}$ yang dapat kita anggap paling fatal di dalam Undang-Undang nomor 19 tahun 2019 tentang perubahan kedua atas Undang-Undang nomor 30 tahun 2002 tentang Komisi Pemberantasan Tindak Pidana Korupsi adalah dengan diamanatkannya oleh undang-undang kepada Dewan Pengawas bahwa Dewan Pengawas bertugas untuk memberikan atau tidak memberikan izin penyadapan, penggeledahan, dan/atau penyitaan. Sedangkan proses hukum telah berjalan dan untuk membuktikan suatu peristiwa hukum atau fakta-fakta pelanggaran hukum yang terjadi maka secara otomatis hal tersebut akan terhambat.

Selanjutnya, yang kembali menjadi pertanyaan penulis adalah apakah Dewan Pengawas merupakan organ pemerintah. Sebab menurut Adrian Sutedi ${ }^{16}$ yang di dalam bukunya ia menuliskan bahwa perizinan di dalamnya harus termuat unsur-unsur salah

15 Ibid.

16 Adrian Sutedi, Hukum Perizinan Dalam Sektor Pelayanan Publik, Jakarta: Sinar Grafika, 2011 , hlm. 200. 
satunya adalah Organ pemerintah. Yang dimaksud dengan organ pemerintah adalah yang menjalankan urusan pemerintah baik di tingkat pusat maupun di tingkat daerah. Menurut Sjahran Basah, dari badan tertinggi sampai dengan badan terendah berwenang memberikan izin. Lalu apakah dewan pengawas merupakan salah satu dari organ pemerintah atau yang biasanya disebut dengan Pejabat. Berdasarkan Teori Organ Pemerintahan, Menurut Anton M. Moeliono dkk ${ }^{17}$, di dalam bukunya mengatakan bahwa Pengertian "Pejabat" menurut pengertian bahasa adalah pegawai pemerintah yang memegang jabatan (unsur pimpinan).

Jika dikaitkan di dalam permasalahan ini maka secara hierarki yang merupakan pejabat di dalam kelembagaan Komisi pemberantas korupsi adalah Pimpinan KPK (Pasal 21 ayat (3) UU No. 19 tahun 2019). Dan didukung dengan UU No. 5 tahun 2014 tentang Aparatur Sipil Negara yang menyebutkan tentang siapa saja yang termasuk ke dalam pejabat Negara, dan salah satunya adalah Ketua dan Wakil Ketua KPK. Sehingga seharusnya yang berhak mengeluarkan izin mengenai suatu tindakan hukum di dalam menjalankan kehendak badan hukum tersebut adalah pimpinan dari lembaga itu sendiri, dalam hal ini adalah Pimpinan KPK. Sehingga jika suatu izin tidak memenuhi salah satu unsur tersebut maka dapat dikatakan izin tersebut cacat materiil, sebab yang mengeluarkan adalah badan pengawas yang kedudukannya di dalam kelembagaan tersebut bukan sebagai Pejabat berwenang. Dewan Pengawas kedudukannya sebagai bagian dari struktural KPK adalah sebagai lembaga pengawas di dalam KPK untuk mengawasi semua kewenangan dan tugas dari KPK agar tidak terjadi perbuatan yang sewenang-wenang. Sehingga dapat kita katakan bahwa salah satu tugas Dewan Pengawas yang dimasukkan di dalam Pasal 37B ayat (1) huruf b tersebut tidak memenuhi syarat atau kontradiksi dengan konsep perizinan dan teori organ pemerintahan itu sendiri. Dewan Pengawas seharusnya dibentuk sebagai dewan yang mengawasi dan mengendalikan tindakan atau perbuatan KPK yang bersifat etik dan moral saja atau pelanggaranpelanggaran terhadap Undang-Undang KPK tersebut, bukan terkait prosedural penanganan di dalam proses pelaksanaan penegakan hukum yang dilakukan penyidik dan penyelidik untuk membuktikan atau mengungkapkan fakta-fakta hukum dan/atau peristiwa hukum yang terjadi. Sebab, jika Dewan Pengawas juga dikaitkan dengan prosedural tindakan penyadapan dalam hal ini terkait pemberi izin dari tindakan penyadapan, maka dikhawatirkan dewan pengawas akan ditunggangi oleh kepentingan-

17 Anton M. Moeliono, dkk., Kamus Umum Bahasa Indonesia, Jakarta: Balai Pustaka, 1995, hlm. 393. 
kepentingan kekuasaan tertentu. KPK juga telah mendapatkan kontrol secara tidak langsung oleh pengadilan. Dimana dalam penetapan tersangka (Putusan MK Nomor 21/PUU-XII/2014), penangkapan, dan penahanan yang di anggap tidak sesuai prosedur dapat diajukan praperadilan, untuk membuktikan sah atau tidak sahnya tindakan tersebut (Pasal 77 KUHAP). Hal itu saja sudah sangat membuat rumit dan membuat KPK kewalahan sebab tidak menutup kemungkinan proses Praperadilan tersebut dimenangkan oleh oknum-oknum tertentu. Kemudian di tambah dengan kehadiran Dewan Pengawas dalam konteks UU No. 19 tahun 2019 itu justru dianggap melemahkan dan memperlambat kinerja KPK.

\section{Izin Dewan Pengawas Dan Kerahasiaan Penyadapan}

Gagasan Dewan Perwakilan Rakyat (DPR) periode 2014-2019 dan Pemerintah yang berupaya mengesahkan berbagai paket kebijakan undang-undang, seperti Kitab UndangUndang Hukum Pidana, Pemasyarakatan, Penyadapan, Tindak Pidana Korupsi dan lain sebagainya, meskipun mendapat berbagai penolakan dengan alasan pelemahan dalam pemberantasan tindak pidana korupsi, DPR dan Pemerintah tak bergeming, salah satu yang berhasil dilakukan adalah pengesahan UU Nomor 19 Tahun 2019 tentang Perubahan Kedua Atas Undang-Undang Nomor 30 Tahun 2002 tentang Komisi Pemberantasan Tindak Pidana Korupsi. ${ }^{18}$ Salah satu yang menjadi kontroversinya adalah pembentukan Dewan Pengawas dan kewajiban perizinan untuk tindakan penyadapan, penggeledahan, dan/atau penyitaan. Tidak dapat dipungkiri praktik penyadapan selama ini menjadi salah satu instrumen yang diandalkan KPK dalam melakukan penyelidikan dan penyidikan, terutama dalam operasi tangkap tangan (OTT). Menurut Pujiono, terkait Rancangan Undang-Undang Penyadapan mendukung untuk tetap meletakan kewenangan penyadapan kepada KPK dalam Undang-Undang organiknya. Pertimbangan tersebut didasarkan pada 3 (tiga) alasan utama yaitu, pertama, secara yuridis tindak pidana korupsi merupakan tindak pidana khusus (serious crime) butuh extra meassure sehingga secara yuridis akan lebih baik tetap berada (diatur) dalam Undang-Undang organiknya; kedua, secara sosiologis, fakta pengungkapan kasus korupsi keberhasilan (utamanya) ditentukan oleh teknik penyadapan; dan ketiga, secara filosofis, penyadapan adalah upaya

18 CNN Indonesia, "Komnas HAM Nilai Polri Berlebihan Tangani Demo September", CNN Indonesia, https://www.cnnindonesia.com/nasional/20191012093542-20-438906/komnas-ham-nilai-polriberlebihan-tangani-demo-september. di akses pada tanggal 16 Agustus 2020. 
pembatasan HAM dikaitkan dengan perlindungan hak atas kebebasan pribadi, akan tetapi perlunya adanya keseimbangan antara hak dan kewajiban asasi dalam pelaksanaannya. ${ }^{19}$ Pujiono $^{20}$ mengingatkan potensi resistensi dari rentang panjang administrasi mekanisme birokrasi penyadapan oleh KPK dalam rezim perizinan yang berakibat pada tidak berfungsinya kewenangan secara optimal, potensi kebocoran ataupun terkendala pada prosedur dan aturan ketat serta birokratis sangat dimungkinkan. Kalau kinerja KPK semakin menurun karena Undang-Undang KPK baru, itu juga akan berimplikasi kepada ekspektasi publik yang juga akan menurun pada lembaga antikorupsi ini. Dan publik dapat beranggapan bahwa pemerintah ingin menjauhkan harapan pemberantasan korupsi yang maksimal di Indonesia.

Berdasarkan beberapa analisis tersebut di atas, maka penulis mengatakan bahwa Berdasarkan konsep hukum penyadapan, WJS Purwodarminto dalam bukunya tentang Kamus Hukum, mengatakan bahwa yang di maksud dengan penyadapan adalah cara mendapatkan keterangan dengan melakukan penyadapan sistem komunikasi pihak sasaran yang dilakukan secara rahasia/clandestine, tanpa diketahui oleh sasaran atau pihak-pihak lain. ${ }^{21}$

Jelas dikatakan di dalam tulisan tersebut bahwa penyadapan dilakukan secara rahasia dan tanpa diketahui oleh sasaran ataupun pihak-pihak lain. Dewan Pengawas dapat digolongkan sebagai pihak lain yang di maksudkan di dalam tulisan WJS Purwodarminto tersebut meskipun berada di dalam tubuh KPK, sebab: (a) Secara historis pembentukan, Dewan Pengawas dibentuk dengan tujuan untuk mengawasi segala kewenangan dan tugas KPK, bukan dibentuk dengan tujuan untuk melakukan prosedural penanganan kasus di dalam KPK; (b) Dewan Pengawas bukan bagian dari pelaku tindakan penyadapan, dimana Dewan Pengawas bukan merupakan Tim atau ketua dari Tim penyelidik atau Tim penyidik KPK; (c) Dewan Pengawas bukan Pimpinan KPK, dimana segala penentuan projustitia (tindakan/kebijakan hukum yang sah) harusnya dilakukan oleh pimpinan KPK; Sehingga meletakkan prosedur izin kepada dewan pengawas dianggap bertentangan dengan sifat kerahasiaan dari tindakan penyadapan itu sendiri dan tidak memenuhi unsur-unsur perizinan sesuai dengan konsep perizinan itu sendiri. Serta berdasarkan analisis teori organ dan UU No. 5 tahun 2014 tentang ASN, yang merupakan pejabat Negara dalam hal ini pejabat yang berwenang dalam hal mengeluarkan perizinan

\footnotetext{
19 Agus Suntoro, Op.cit., hlm. 30.

20 Ibid.

21 WJS Purwodarminto, Kamus Hukum, Bandung: Citra Umbara, 2008, hlm. 346.
} 
adalah KPK dan wakil KPK. Dan hal tersebut didukung oleh pasal 21 ayat (3) yang menyatakan bahwa Pimpinan KPK merupakan Pejabat Negara. Menurut Konsep perizinan menurut Adrian Sutedi ${ }^{22}$, salah satu unsur perizinan yang harus dipenuhi adalah organ pemerintahan. Yang dimaksudkan adalah bahwa Izin harus dikeluarkan oleh pejabat berwenang. Dari semua hal tersebut di atas tentu saja riskan melemahkan kedudukan pimpinan KPK dan sifat independensi dari KPK sebab dapat dianggap bahwa KPK mendapatkan intervensi dari dalam tubuhnya sendiri. Sedangkan berdasarkan putusan Mahkamah Konstitusi nomor 012-016-019/PUU-IV/2006, Mahkamah Konstitusi berpendapat bahwa rumusan pasal independensi KPK berarti bebas dari pengaruh mana pun dalam melaksanakan tugas dan wewenangnya sehingga tidak terdapat persoalan konstitusionalitas dalam pasal tersebut. Salah satu wewenang KPK yang dimaksudkan dalam hal ini adalah wewenang melakukan penyadapan sebagai keperluan melaksanakan tugas penyelidikan dan penyidikan.

\section{KESIMPULAN}

Bahwa berdasarkan pasal 37A ayat (1) Undang-Undang Nomor 19 Tahun 2019 tentang Perubahan Kedua atas Undang-Undang Nomor 30 Tahun 2002 tentang Komisi Pemberantasan Tindak Pidana Korupsi, Kedudukan Dewan Pengawas di dalam kelembagaan KPK adalah sebagai lembaga Pengawas pelaksanaan tugas dan wewenang Komisi Pemberantasan Korupsi. Kedudukan Dewan Pengawas sebagai pemberi izin terkait tindakan penyadapan tidak sesuai dan/atau bertentangan dengan Peraturan perundang-undangan dan Teori organ pemerintahan serta konsep Perizinan. Dewan pengawas pun tidak masuk dalam kategori independent body sebab Dewan Pengawas KPK menjadi satu kesatuan organisasi dengan KPK melekat bersama dengan Pimpinan KPK dan Pegawai KPK (Pasal 21 ayat 1 UU No. 19 tahun 2019). Dewan Pengawas dikatakan Mandiri dalam hal terkait pembuatan keputusan mengenai pelaksanaan tugasnya sebab tidak membutuhkan persetujuan dari Pimpinan KPK dan Dewan Pengawas mempertanggung jawabkan tugasnya langsung kepada Presiden RI dan Dewan Perwakilan Rakyat RI (Pasal 37B ayat (2) dan (3) UU No. 19 tahun 2019), bukan kepada pimpinan KPK. Selain itu, bahwa kewajiban meminta izin tertulis kepada Dewan Pengawas terkait tindakan penyadapan bertentangan dengan sifat kerahasiaan tindakan penyadapan. Karena, Dewan Pengawas bukan Penyelidik atau Penyidik KPK dan bukan bagian dari Tim tersebut.

22 Adrian Sutedi, Op.cit., hlm. 201-202. 
Dewan Pengawas bagian eksternal dari Tim penyelidik dan penyidik, kedudukannya sebagai lembaga pengawas. Dewan Pengawas KPK diangkat dan ditetapkan oleh Presiden Republik Indonesia, termasuk pemilihan Ketua Dewan Pengawas sehingga secara konseptual dan implementasi sangat tergantung pada wajah kekuasaan Presiden pada periode pengangkatan (Pasal 37E ayat 1 dan ayat 10), sehingga sifat kerahasiaan dari penyadapan itu sendiri akan sangat diragukan terlebih ketika perkaranya menyangkut dengan pemegang utama organisasi kekuasaan tersebut. Ketidaksesuaian yang lain adalah bahwa Dewan Pengawas KPK menggantikan peran dan fungsi peradilan terutama berkaitan dengan keseluruhan proses penegakan hukum di antaranya meliputi penyadapan, penggeledahan dan penyitaan padahal fungsinya bukan sebagai bagian dari penegakan hukum dalam criminal justice system.

\section{Daftar Pustaka}

\section{Buku}

Djaja, Ermasjah, Memberantas Korupsi Bersama Komisi Pemberantasan Korupsi, Edisi Kedua, Jakarta: Sinar Grafika, 2010.

Huda, Ni'matul dan Imam Nasef, Penataan Demokrasi dan Pemilu di Indonesia Pasca Reformasi, Jakarta: Kencana, 2017.

Ibrahim, Johni, Teori dan Metodologi Penelitian Hukum Normatif, cetakan III, Malang: Bayumedia Publishing, 2007.

Marzuki, Peter Mahmud, Penelitian Hukum, Jakarta: Prenada Media Group, 2011.

Moeliono, Anton M., dkk., Kamus Umum Bahasa Indonesia, Jakarta: Balai Pustaka, 1995.

Purwodarminto, WJS, Kamus Hukum, Bandung: Citra Umbara, 2008.

Sutedi, Adrian, Hukum Perizinan Dalam Sektor Pelayanan Publik, Jakarta: Sinar Grafika, 2011.

\section{Jurnal dan Makalah}

Setiadi, Wicipto, "Korupsi di Indonesia (Penyebab, Bahaya, Hambatan dan Upaya Pemberantasan, Serta Regulasi)”, Jurnal Legislasi Indonesia, Vol 15, No. 3, November 2018.

Suntoro, Agus, "Penyadapan dan Eksistensi Dewan Pengawas Komisi Pemberantasan Tindak Pidana Korupsi”, Jurnal Legislasi Indonesia, Vol. 17 No. 1, 2020. 


\section{Situs Web}

CNN Indonesia, "Komnas HAM Nilai Polri Berlebihan Tangani Demo September", CNN Indonesia, https://www.cnnindonesia.com/nasional/20191012093542-20438906/komnas-ham-nilai-polri-berlebihan-tangani-demo-september. di akses pada tanggal 16 Agustus 2020.

CNN Indonesia, "KPK Tak Butuh Dewan Pengawas", CNN Indonesia, https://www.cnnindonesia.com/nasional/20190910082044-20-428971/kpktak-butuh-dewan-pengawas, diakses pada tanggal 02 Maret 2020.

Pambudhi, Hario Dhanang, “Tinjauan Ketatanegaraan Dewan Pengawas KPK”, Fakultas Hukum Universitas Padjadjaran, http://fh.unpad.ac.id/tinjauan-ketatanegaraandewan-pengawas-kpk/, diakses pada tanggal 12 Agustus 2020.

Prabowo, Haris, "Jokowi Setujui SP3 Kasus Korupsi dan Dewan Pengawas di Revisi UU KPK”, Tirto.id, https://tirto.id/jokowi-setujui-sp3-kasus-korupsi-dewan-pengawas-direvisi-uu-kpk-eh1X, diakses pada tanggal 11 Agustus 2020.

Putri, Klareza, "Masa Depan Pemberantasan Korupsi Pasca Revisi UU KPK”, Economica.id, https://www.economica.id/2019/09/20/masa-depan-pemberantasan-korupsipasca-revisi-uu-kpk/, diakses pada tanggal 02 Maret 2020.

Salim, Hanz Jimenez, "Mahfud MD Dukung Pembentukan Dewan Pengawas KPK", Liputan6, https://www.liputan6.com/news/read/4063398/mahfud-md-dukungpembentukan-dewan-pengawas-kpk, diakses pada tanggal 11 Agustus 2020.

Sutopo, Adnan, "Peran Strategis Komisi Pemeberantasan Korupsi", Antikorupsi.org, https://antikorupsi.org/id/news/peran-strategis-komisi-pemberantasankorupsi, diakses pada tanggal 27 Januari 2020. 